\title{
WWP1 wt Allele
}

National Cancer Institute

\section{Source}

National Cancer Institute. WWP1 wt Allele. NCI Thesaurus. Code C98118.

Human WWP1 wild-type allele is located in the vicinity of $8 \mathrm{q} 21$ and is approximately 136

kb in length. This allele, which encodes NEDD4-like E3 ubiquitin-protein lig ase WWP1 protein, is involved in the modulation of protein ubiquitination. 